\title{
La enseñanza de ecología en el primer año universitario: construcción de una estrategia posible
}

Marchese, Mercedes R.*; Rossi, Liliana M.* y Chemes, Silvina B.*

\section{Resumen}

Se presenta una propuesta de enseñanza construida durante los últimos siete años, vinculada a la incorporación de la materia Ecología General en el diseño curricular del primer año de las carreras de Licenciatura en Biodiversidad y Profesorado en Biología, de la Facultad de Humanidades y Ciencias ( Universidad Nacional del Litoral). Se recuperan experiencias pedagógicas y se contribuye al debate sobre las prácticas de enseñanza universitaria con alumnos ingresantes. Desde una perspectiva didáctica, los ingresantes definen una problemática común para las cátedras, y su abordaje demanda un continuo trabajo de los equipos docentes. Esta propuesta se estructura promoviendo una fuerte vinculación teoría/práctica, asumiendo que la diversidad de tipos de trabajos prácticos favorece la construcción del conocimiento y el desarrollo de múltiples competencias en los alumnos. Los diseños se vinculan con aquellas actividades propias del descubrimiento y validación de conocimientos en Ecología: trabajos de campo, trabajos experimentales en laboratorio, resolución de problemas, aplicación de modelos de simulación, búsqueda, lectura y discusión de fuentes bibliográficas. La intervención docente se propone como moderadora en el desarrollo de los trabajos grupales, y motivadora para la identificación y resolución de problemas.

Palabras clave: Ecología General; Ingresantes universitarios; Prácticas de enseñanza

\section{Abstract}

The education of Ecology in the first university year and the construction of a possible strategy. Strategies of teaching in relationship to the incorporation of General Ecology in the curriculum of the first year of the careers of Licentiate in Biodiversity and Professor of Biology (National University of the Littoral) are presented. From a didactic perspective, the undergraduate students have a common problematic, and his boarding demands a continuous work on activities to improve teaching and student learning. This teaching and

\footnotetext{
* Cátedra de Ecología. Facultad de Humanidades y Ciencias, Universidad Nacional del Litoral.E-mail:schemes@fhuc.unl.edu.ar
} 
learning proposal is based on the main traits all ecologists share are curiosity, creativity, a passion for observation and scientific inquiry, enthusiasm for asking and answering hard questions. Thus, field trips, collaborative experimental laboratory activities, motivating students to participate in a discussion and solving problems, simulated models application, innovative lecture to improve teaching and student learning are the teach and advise students by the professors.

Keywords: General Ecology, undergraduate students; teaching and learning strategies 